\title{
INSTRUCTORS’ PERCEPTIONS OF THEIR ROLE IN ONLINE GROUP WORK
}

\author{
Lyndall Cooper-Smith ${ }^{1}$, Bill Davey ${ }^{2}$ and Arthur Adamopoulos ${ }^{2}$ \\ ${ }^{I} \mathrm{PhD}$ Candidate \\ ${ }^{2} \mathrm{Dr}$. \\ RMIT University, Melbourne, Australia
}

\begin{abstract}
Amidst the proliferation of online higher education courses, instructors are not readily adopting online group work. Yet, group work is recognised as important to the development of collaborative teamwork skills. Employers of business graduates consider collaborative teamwork skills as one of the most important to look for in a prospective employee. By understanding the perceptions instructors have about their role in group work, then ways can be found to increase the use of online group work as a means of addressing this problem.

Individual practices of group work were examined. Data was gathered in three stages from instructors and educational developers. The data was analysed using a phenomenographic approach. The outcomes of the research are reported as five categories of conception, which are: Starter; Co-ordinator; Trusted Advisor; Evaluator; and Actuator. Within the categories, four dimensions of variation are shown in a hierarchical structure of low complexity to comprehensive. The categories of conception and the dimensions of variation describe all of the conceptions found during analysis. The categories do not describe individuals but capture the conceptions of the respondents in a finite set of categories of conception.

The outcomes of this research have the potential to inform instructors new to online group work or those striving to improve their practice.
\end{abstract}

\section{KEYWORDS}

Collaborative Online Group Work, Phenomenography, The Instructor

\section{INTRODUCTION}

Group work is recognised as a learning tool that facilitates collaborative learning (Oliveira et al., 2011), has been widely adopted in Australian higher education (Baskin et al., 2005, Koh and Hill, 2009), and, is thought of as "an important preparation for professional careers, providing a level of real-world authenticity" (Smith et al., 2011)(p.121). Online group work has the potential to optimize student learning (Chang and Kang, 2016). "Why then is online group learning not more widely practiced, particularly within higher education?" (Roberts and McInnerney, 2007)(p.257).

Within academia, it is likely that we would find quite different experiences and conceptions about teaching online courses. Offering online group work then, raises a whole different set of experiences, anecdotes and advice. Taking a phenomenograph approach to understand the individual experiences of instructors in group work, we can construct a collective viewpoint of the phenomenon.

The purpose of this study was to better understand the phenomenon of the instructors' role in online group work. By identifying conceptions of instructor's role we are better able to characterise a set of categories of conception of the phenomenon. Phenomenographic analysis resulted in five categories of conception which classify the roles of instructors in online group work. These categories help us understand instructors and so enable us to influence them to provide better online student experiences. 


\section{BACKGROUND}

The role of the instructor in online group work cannot be understated (Arbaugh, 2008). Their role is significant, from the conception of the learning task, managing the formation of the groups, questioning, responding to questions, keeping the groups focused, to grading group presentations. Goold et al. (2010) found that the instructor, because of their discipline expertise, is able to scaffold learning that builds student engagement to promote deep learning. Whereas, Rienties et al. (2013) argued that to be successful in online instruction, the instructor should be a content (discipline) expert, understand learning pedagogy and also be a proficient technology user. More recently, Salmon et al. (2015) advanced the view that there is an urgency for educational institutions to build the capacity of their instructors to "embrace forward-looking learning design" (p.543) for blended, online and mobile learning.

Laurillard (2012) strongly argued that instructors must resist the notion that technology allows students to do it all themselves. Laurillard (2012) validated this point by asserting that instructors have a more critical role in scaffolding the learning to support students to think and develop their new skills using digital technology. This researcher argued that in a technology-led education environment, it is now time to shift the focus from learning to instruction; quality instruction.

In adult education, constructivist pedagogy substantiates that knowledge is not simply transmitted from one person to another, learning is as a result of interaction by acquisition, enquiry, discussion, practice and collaboration (Laurillard, 2012). The instructor's role is extremely important in creating an environment conducive to collaborative and participative online learning (Oliveira et al., 2011).

Urhahne et al. (2010) researched the role of the instructor in computer-supported collaborative inquiry learning. An outcome of their research was the five principles for the role of the teacher; the 5E Model. The five principles of their 5E Model are: 1) envision the lesson; 2) enable collaboration; 3) encourage students; 4) ensure learning; and, 5) evaluate achievement. These principles span the whole instructional process from planning to assessment (Urhahne et al., 2010). Together, the principles provide a blue-print for the role of the instructor. Each of the Urhahne et al. (2010) principles are summarily outlined:

1) Envision the learning: In this stage the instructor has the role of planner, organiser and decision maker. Course content, software applications, learning tasks, assessment tasks, communication and administrative processes have to be considered and accommodated.

2) Enable collaboration: In this stage the instructor has to ensure the students have the means to collaborate with each other for the facilitation of knowledge exchange. At times the instructor may need to over-ride student-to-student exchanges.

3) Encourage students: In this stage the instructor is not always a silent bystander, their role is to react flexibly to encourage interactions, to clarify and to spark the learning.

4) Ensure learning: In this stage the instructor is ensuring that the discipline-specific knowledge is being learnt by questioning, challenging and offering praise.

5) Evaluate achievement: In the final stage the instructor undertakes assessment and provides feedback. Comparative assessment grades provide the instructor with the means to evaluate their instructional effectiveness.

The 5E Model identifies each of the multifaceted tasks within each of the roles the instructor has in collaborative learning, in fact, there is no stage where the instructor is passive or redundant (Urhahne et al., 2010). The 5E Model attributes an "active, planning, supporting, and evaluating function" to the instructor (Urhahne et al., 2010)(p.240). The Urhahne et al. (2010) research outlines that an instructor has many tasks, hence the $5 \mathrm{E}$ Model is a guide to practice.

Other studies have sought to identify the role of the instructor in group work. From the research of Young (2006), Arbaugh (2010) and Bigatel et al. (2012) it was claimed that effective online instruction was based on the instructor competence, with social presence and teacher presence being critical factors. In his study, Kraiger (2008) specifically asked: is an instructor implicitly and explicitly aware of their role in group work? One of the key challenges Urhahne et al. (2010) had when attempting to apply the outcomes of their multi-media research into the classroom, was accurately distinguishing the role of the instructor as either teacher, coach, moderator, or decision-maker. More recently, Salmon et al. (2015) advanced the view there is an urgency for educational institutions to build the capacity of their instructors to "embrace forward-looking learning design" (p.543) for blended, online and mobile learning. This research examines the conceptions of instructors with the objective of determining patterns of instruction. 


\section{THE RESEARCH SPACE}

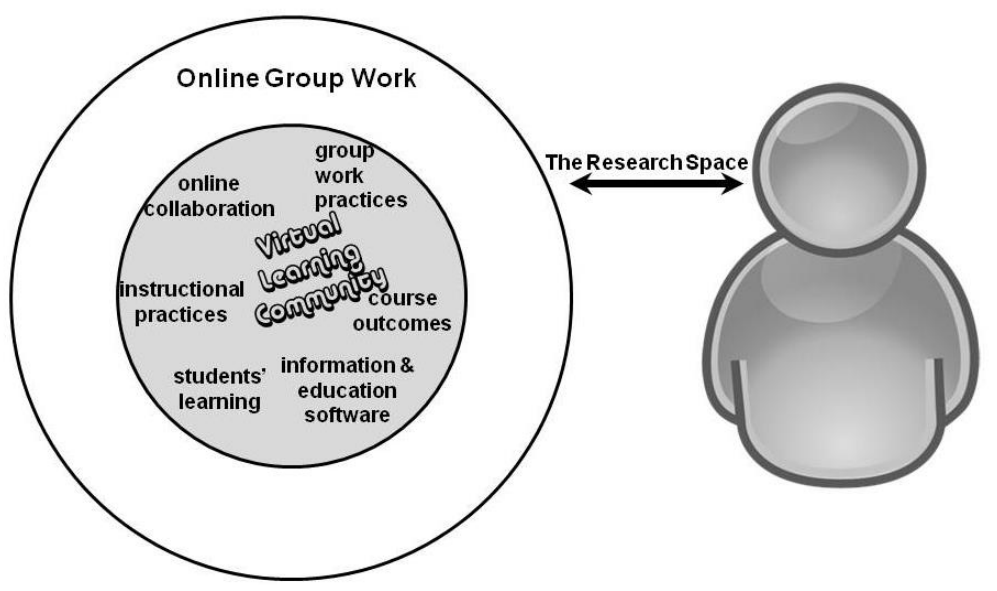

Figure 1. The Research Space

In Figure 1, the research space is diagrammatically represented as the instructor's role in offering online group work within a complex virtual learning community environment. The study is not of group work per se, but the conceptions of the instructor of their role in group work. Phenomenography seeks to represent "all of the data very faithfully" (Walsh, 2000)(p.27) by capturing all of the perceptions, from vague to vivid representations. Phenomenography focuses on the perspective of others, rather than the perspectives of the researcher (Andretta, 2007).

\section{PHENOMENOGRAPHY}

Taking a phenomenographic approach, the intention of the research design was to gather a broad range of instructor perceptions. Phenomenography is "a rigorous, empirical exploration of the qualitatively different ways in which people experience and conceptualize various phenomena" (Marton, 2000)(p.103). Which follows, that the aim of phenomenographic research is not to classify people, or compare groups, or the presentations made by groups, but focuses on conceptions of a phenomenon (Marton, 1981).

\subsection{Research Question}

This study was part of a larger study aimed at discovering the lived experiences of group work by both academics and educational developers. This paper deals with the central research question, which is stated as:

What are the conceptions of instructors of group work?

\subsection{The Research Participants}

The participants in this research were academics and educational developers employed at fully accredited universities. Metropolitan and regional universities around Australia were represented in this study. All these universities offer on-campus, blended and wholly online graduate courses. In each of their respective employment roles, the research participants are responsible for the development or delivery of a wide variety of higher education courses. Each participant was invited to participate in the research because of their expertise in teaching and learning in virtual learning communities, and more specifically group work. Data was gathered using an online Delphi study, an online questionnaire and semi-structured face-to-face interviews. 


\subsection{Online Delphi Study}

Nine educational developers participated in the online Delphi study. Over three rounds, participants provided responses to questions and statements relating to group work and online group work.

\subsection{Online Instructor Questionnaire}

Twenty-one academics participated in the online instructor questionnaire. The online questionnaire consisted of seventeen questions relating to group work and their instructional role. The questions were presented as multiple choice, yes/no, true/false and short answer.

\subsection{Semi-structured Face-to-face Interviews}

Seventeen semi-structured face-to-face interviews were conducted with academics. Ethics approval to record interviews was granted and recorded interviews were subsequently transcribed verbatim. Trigwell (2000)(p.63) argued that phenomenographers "view that meaning is constituted in the relation between the person and the phenomenon". Using semi-structured face-to-face interviews, the instructors' lived experiences of group work were sought. An adapted interview questioning technique of what, why and how (Couger, 1996), supported with prompting strategies (Pitts and Browne, 2007) was implemented. Prior to undertaking the first interview, training using a mock-interview technique was facilitated by the senior and associate researchers.

The interview guide consisted of 11 questions. All participants were asked the same questions, with some responses followed up with another question for verification, for example: what did you mean, or, can you provide an example? The motivation for asking a follow-up question was to delve into the instructor's preconceived conception of their specific experience in a specific situation of group work facilitation. Walsh (2000) identified that being sensitive to what the participant is saying, is a means of guiding the research to achieve its' objectives.

\section{DATA COLLECTION AND ANALYSIS}

Phenomenographers use open, explorative data collection to examine the different ways a phenomenon can be experienced (Cope, 2004). Short-answer text and interview questioning were the predominant means of generating data in this research. The aim of the data collection was to "capture the utterances" of academics relating to group work (Cope, 2004)(p.7). Interviews are the most common means of gathering data in phenomenography (Walsh, 2000). The output space of the research was a combined data set. Data analysis commenced during the transcription of the recorded interviews.

\subsection{Data Analysis}

When transcribing the instructor interviews, it was important to be particularly attentive to what the participant had said as a means of revealing the participant's understanding of the phenomenon (Walsh, 2000). Each participant told a different story.

Data analysis in phenomenography is an iterative process, allowing the categories that are in the data to emerge progressively as the repetitions of the data analysis proceeds (Walsh, 2000). As Walsh (2000) contends, in phenomenographic analysis, the discovery is the understanding of particular ways in which the participants describe their experience of the phenomenon.

Each of the particular ways the participant expressed their perspectives of the phenomenon was examined for common, similar and contrasting conceptions. By identifying and recording the common, similar and contrasting conceptions, "a limited number of distinctively different ways of understanding the phenomenon" became evident (Marton, 1994)(p.4425). It was the dimensions of variation of the instructors' perceptions which formed the categories of conception. Whilst all of the categories differ, each category is linked to the next category. It is the dimensions of variation that the instructor displayed that connects one category to the next. The dimensions of variation being the constituent part of something being experienced (Marton \& Booth, 1997). The data shows that the proficiency of the instructor can be represented as a hierarchy of basic to comprehensive group work proficiency. 


\section{RESEARCH FINDINGS}

Analysis of the data revealed five separate, yet linked phenomenographic categories of conception. The five categories of conception found in the data are: Starter; Co-ordinator; Trusted Advisor; Reflector; and Actuator. Each of the categories of conception is linked by dimensions of variation. Marton and Booth describe dimensions of variation as being constituent parts of how something is experienced. In phenomenography, the phenomenographer uses the dimensions of variation found in the data as a means of presenting focal awareness to each of the categories of conception. Each of the categories of conception is presented now as summary role descriptors inclusive of aspects of practice. An aspect of practice (AOP) is the overarching description of the way a category of conception is expressed in terms of the reported practice of the instructor.

\section{Role Descriptor}

Starter

Descriptor: set-and-forget; relinquisher

This role recognises the value of information and education technology, yet collaborative group work is often relinquished for other forms of learning that deliver the course content as instructor-led learning, preferring to work with individual students. The instructor either decides not to adopt group work, or uses a minimalist set-and-forget control of group work.

AOP: not present

Co-ordinator Descriptor: co-ordinates the day-to-day processes of group work

The role of co-ordinator is a minimalist of information management, who prefers to adopt, use and re-use technology-based educational software to manage groups and course content.

AOP: present, responds minimally

Trusted Advisor Descriptor: provides advice, prepared to intervene

The role of a trusted advisor is an instructor who is present, focused, informed, and a proactive user of education technology for instructional-related practices, they are sufficiently confident to intervene in potential issues and provide guidance.

AOP: present, responsive, proactive, a guide

Reflector

Descriptor: reflects on processes and outcomes

The reflector uses reflective practice to build their proficiency. This role is informed and can argue for and against the use of group work with the confidence of knowledge.

AOP: present, responsive, proactive, aware, reflective, a guide

Actuator Descriptor: able to incite, influence and move others to engage and achieve.

High levels of motivation for inclusivity and collaboration in online group work are actuated. High levels of expertise of collaboration-based software and its' application are evident. This role demonstrates all of the attributes of the role descriptors.

AOP: enthusiastically present, responsive, proactive, aware, reflective, a guide 


\section{Categories of Conception}

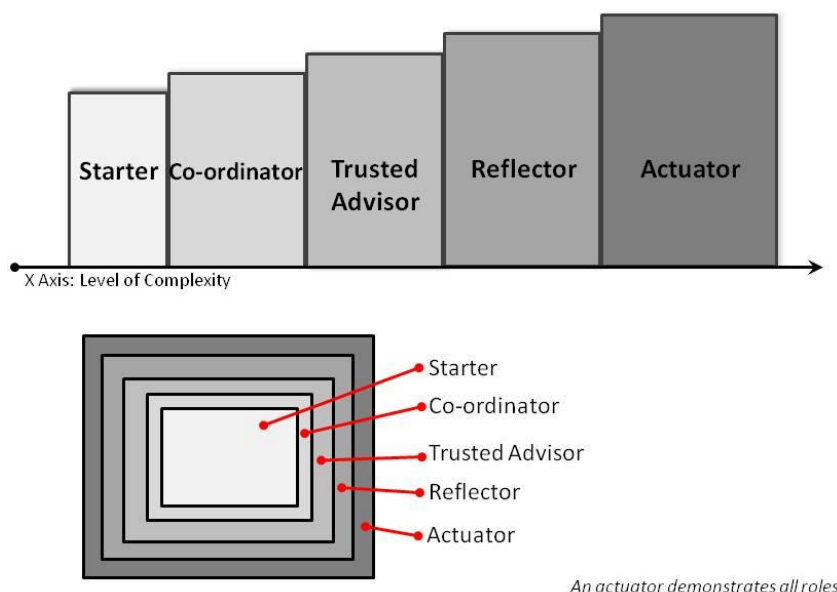

Figure 2. Categories of Conception

In Figure 2: The Categories of Conception are diagrammatically represented. These categories provide focus on each of the individual conceptions that describe the various complex roles of the instructor found in the data. The roles can be shown as a level of complexity of basic to comprehensive; the descriptor of starter at the basis, and core of the hierarchy.

Four dimensions of variation existed in the data. The dimensions of variation show the differences between each category. The dimensions of variation, as well as aspects of practice (AOP) found in the data are presented in Table 1.

Table 1. Dimensions of Variation

\begin{tabular}{|c|c|c|c|c|c|}
\hline & Starter & Co-ordinator & Trusted Advisor & Reflector & Actuator \\
\hline AOP & $\begin{array}{l}\text { Non-Starter, } \\
\text { not present }\end{array}$ & $\begin{array}{l}\text { present, minimal } \\
\text { responses }\end{array}$ & $\begin{array}{l}\text { present, } \\
\text { responsive, } \\
\text { proactive, a } \\
\text { guide }\end{array}$ & $\begin{array}{l}\text { present, aware, } \\
\text { responsive, } \\
\text { reflective, a guide }\end{array}$ & $\begin{array}{l}\text { enthusiastically } \\
\text { present, aware, } \\
\text { reflective, a } \\
\text { guide }\end{array}$ \\
\hline \multicolumn{6}{|c|}{ Dimensions of Variation } \\
\hline $\begin{array}{l}\text { The Instructor } \\
\text { Cognition }\end{array}$ & $\begin{array}{l}\text { prefers to work } \\
\text { with individual } \\
\text { students }\end{array}$ & $\begin{array}{l}\text { can express the } \\
\text { benefits of } \\
\text { collaborative } \\
\text { online group } \\
\text { work }\end{array}$ & $\begin{array}{l}\text { aware and } \\
\text { confident of their } \\
\text { role and } \\
\text { supportive of } \\
\text { students and } \\
\text { other instructors }\end{array}$ & $\begin{array}{l}\text { knowledgeable, } \\
\text { proactive, } \\
\text { reflective, } \\
\text { encourages others }\end{array}$ & $\begin{array}{l}\text { influential, } \\
\text { demonstrates } \\
\text { substantial } \\
\text { expertise }\end{array}$ \\
\hline $\begin{array}{c}\text { Group Work } \\
\text { Processes }\end{array}$ & $\begin{array}{l}\text { lacks confidence, } \\
\text { reticent to inform } \\
\text { others about } \\
\text { group work } \\
\text { processes }\end{array}$ & $\begin{array}{l}\text { provides groups } \\
\text { with instruction } \\
\text { on roles and } \\
\text { processes. } \\
\text { Co-ordinates } \\
\text { day-to-day } \\
\text { processes. }\end{array}$ & $\begin{array}{l}\text { trusted guide, } \\
\text { responsive to } \\
\text { individuals and } \\
\text { groups }\end{array}$ & $\begin{array}{l}\text { experienced, } \\
\text { proactive, } \\
\text { reinforces good } \\
\text { practice }\end{array}$ & $\begin{array}{l}\text { inspires and leads } \\
\text { groups and other } \\
\text { instructors }\end{array}$ \\
\hline $\begin{array}{l}\text { Use of } \\
\text { Collaborative } \\
\text { ICT }\end{array}$ & personal use only & $\begin{array}{l}\text { engages with } \\
\text { groups to adopt a } \\
\text { range of software } \\
\text { platforms for } \\
\text { collaboration }\end{array}$ & $\begin{array}{l}\text { engages and can } \\
\text { recommend } \\
\text { software for a } \\
\text { particular } \\
\text { collaborative } \\
\text { environment }\end{array}$ & $\begin{array}{l}\text { engages and can } \\
\text { recommend } \\
\text { software for a } \\
\text { particular } \\
\text { collaborative } \\
\text { environment }\end{array}$ & $\begin{array}{l}\text { recommends } \\
\text { specific software } \\
\text { applications for } \\
\text { specific group } \\
\text { cohorts }\end{array}$ \\
\hline $\begin{array}{l}\text { Reflective } \\
\text { Practice }\end{array}$ & $\begin{array}{l}\text { is not aware and } \\
\text { does not reflect } \\
\text { on their } \\
\text { professional } \\
\text { practice }\end{array}$ & $\begin{array}{l}\text { minimal } \\
\text { reflection of role } \\
\text { and outcomes }\end{array}$ & $\begin{array}{l}\text { uses their } \\
\text { experience as a } \\
\text { positive } \\
\text { influence }\end{array}$ & $\begin{array}{l}\text { uses reflective } \\
\text { practice to build } \\
\text { on their practice }\end{array}$ & $\begin{array}{l}\text { demonstrates and } \\
\text { espouses the } \\
\text { benefits of } \\
\text { reflective } \\
\text { practice }\end{array}$ \\
\hline
\end{tabular}


Table 1 identifies the hierarchy of the dimensions of variation that indicate the instructor's role in the implementation of group work.

Within the categories of conception, the data revealed four critical dimensions. The dimensions of: the instructor cognition; group work processes; use of collaborative ICT; and reflective practice are practical applications of the instructors' perceptions. The progression of variation within each dimension increase in complexity across the table. Each of the dimensions of variation is now presented as descriptors:

The Instructor Cognition: is the thinking, perception and mindfulness the instructor has about their instructional role in group work. The variation ranges from the basic cognition of the instructor's thoughts that are motivated by the needs of self, to the more comprehensive instructor cognition where their motivation is the success of others.

Group Work Processes: is the dimension of variation that recognises the instructor cognition of group work training. At the lower end of proficiency, the instructor does not provide training on group work processes. At the higher end, comprehensive training is provided as a means of enabling groups to evolve into effective entities.

Collaborative ICT: the dimension of variation relating to the use of collaborative software in group work. At the lower end of the dimension of ICT use, the instructor finds collaborative software problematic, preferring not to recommend any particular application. At the higher end, the instructor is able to recommend specific collaborative software applications for specific group projects.

Reflective Practice: this dimension of variation recognises reflective practice as an enabler of future practice. At the lower end of the dimension the instructor is not aware of their impact on groups and group work, preferring not to over think their role. At the higher end, the instructor constantly reflects on the impact of their role and uses this reflection to guide future practice.

\section{DISCUSSION}

The findings show that the perceptions of instructor's role in online group work can be represented by phenomenographic categories of conception. The categories of conception are separate, yet linked by dimensions of variation. The categories of conception found in this research are: Starter; Co-ordinator; Trusted Advisor; Reflector; and Actuator. These categories of conception describe the perceptions the instructor has about their role in online group work. The participants in this study spoke of very different experiences of group work and online group work.

Humans can be aware of a specific detail of their experience, and yet not always simultaneously aware of the overall impact of that specific detail (Marton, 2000). Instructors of group work are aware of their responsibility to lead and manage the students through the process of group work. Yet, simultaneously they may not be aware of that their role shifts and changes throughout the process, seeing themselves in the separate roles of starter, co-ordinator, advisor or reflector. More importantly, the data showed that rarely do they consider themselves to be an actuator of group work, an enabler, where the combination of all of these roles facilitates the groups to achieve heightened success.

Should it be reported that the practice of online group work is declining, further research is warranted. Research into group work has shown that students find working in groups difficult, frustrating and often unproductive for many reasons, one of which is the potential for conflict between group members (Roberts and McInnerney, 2007); (Koh and Hill, 2009); (Smith et al., 2011). How then can we develop the capacity of instructors as well as the enthusiasm of students in online group work?

The findings of this research resonate with Arbaugh (2008), the role of the instructor cannot be understated; a role that goes beyond the contention that in an online environment the instructor simply transitions from "knowledge disseminator to that of interaction facilitator" (p.1236). 


\section{CONCLUSION}

At the outset it was introduced that group work facilitates collaborative learning and is widely recognised by employers as preparation for team work, yet research has established that online group work is not widely practiced. Through phenomenography this research aimed to examine patterns of instruction in group work and online group. The findings show that the role of the instructor is identified as five categories of conception. The five categories of conception are: starter; co-ordinator; trusted advisor; reflector; and actuator.

By creating an awareness, or collective consciousness for the instructor, it is possible to open each instructor up to the next level in the hierarchical categories of conception, and improve group work proficiency. Marton and Booth (1997) depict the nature of awareness as a framework where the person's awareness is implied by their understanding, whilst being aware of certain parts of the situation, or phenomenon, and only tacitly aware of other parts. Further, that the phenomenon is understood through the situation in which it occurred, and yet our experience can be modified, transformed and developed by focusing on the situation (Marton and Booth, 1997).

Earlier, the role of starter was described as set-and-forget and a relinquisher of group work. The research found that the starter had made a conscious decision not to offer group work, either preferring to work with individual students, or choosing to relinquish their responsibilities of managing groups to the students. By creating an awareness, or collective consciousness for the need of instructor-responsibility, it is contended that is possible to move the Starter to the higher category of conception of Co-ordinator. Similarly, to move the Co-ordinator to the Trusted Advisor category, it would be necessary to promote the awareness of being engaged in the group work situation, to be confident of their role and be willing to provide comprehensive instruction. To move to the next higher category of conception of Reflector, the benefits of reflexive practice would need to be shown. Lastly, an Actuator of group work was found to be an instructor who animates, inspires and stimulates groups to become high achieving entities. To move to the Actuator category from the Reflector category it would be necessary to create an awareness or collective consciousness of the need to be an actuator of group work.

It is concluded, by raising the awareness, or collective consciousness of the instructor's role, that any improvement in the proficiency and uptake of online group work can be achieved.

\section{REFERENCES}

Andretta, S. 2007. Phenomenography: a conceptual framework for information literacy education. Aslib Proceedings: New Information Perspectives, 59, 152-168.

Arbaugh, J. B. 2008. Instructors as Facilitators of Learner-Learner Interaction in Third-Generation Learning Environments. Industrial and Organizational Psychology, 1, 487-490.

Arbaugh, J. B. 2010. Sage, guide, both, or even more? An examination of instructor activity in online MBA courses. Computers and Education.

Baskin, C., Barker, M. \& Woods, P. 2005. When group work leaves the classroom does group skills development also go out the window? British Journal of Educational Technology, 36, 19-31.

Bigatel, P. M., Ragan, L. C., Kennan, S., May, J. \& Redmond, B. F. 2012. The identification of competencies for online teaching success. Journal of Asynchronous Learning Networks, 16.1, 59.

Chang, B. \& Kang, H. 2016. Challenges facing group work online. Distance Education, 37:1, 73-88.

Cope, C. 2004. Ensuring validity and reliability in phenomenographic research using the analytical framework of a structure of awareness. Qualitative Research Journal, 4, 5-18.

Couger, J. D. 1996. Creativity and Innovation in Information Systems Organizations, Danvers, MA. USA, Boyd and Fraser Publishing Co.,

Goold, A., Coldwell, J. \& Craig, A. 2010. An examination of the role of the e-tutor. Australasian Journal of Educational Technology, 26(5), 704-716.

Koh, M. H. \& Hill, J. R. 2009. Student Perceptions of Group Work in an Online Course: Benefits and Challenges. Journal of Distance Education, Vol. 23, 69-92.

Kraiger, K. 2008. Third-Generation Instructional Models: More About Guiding Development and Design Than Selecting Training Methods. Industrial and Organizational Psychology, 1, 501-507.

Laurillard, D. 2012. Teaching as a Design Science, New York and London, Routledge. 
Marton, F. 1981. Phenomenography - Describing Conceptions of the World Around Us. Instructional Science, 10, 177-200.

Marton, F. 1994. Phenomenography. In: Husen, T. \& Postlethwaite, T. N. (eds.) The International Encyclopedia of Education. Second ed. Oxford, England: Elsevier Science Ltd.

Marton, F. 2000. The structure of awareness. In: Bowden, J. A. \& Walsh, E. (eds.) Phenomenography. Melbourne: RMIT University Press.

Marton, F. \& Booth, S. 1997. Learning and Awareness, Mahway, New Jersey 07430, Lawrence Erlbaum Associates.

Oliveira, I., Tinoca, L. \& Pereira, A. 2011. Online group work patterns: How to promote a successful collaboration. Computers \& Education, 57, 1348-1357.

Pitts, M. G. \& Browne, G., J. 2007. Improving requirements elicitation: an empirical investigation of procedural prompts. Info Systems Journal, 17, 89-110.

Rienties, B., Brouwer, N. \& Lygo-Baker, S. 2013. The effects of online professional development on higher education teachers' beliefs and intentions towards learning facilitation and technology. Teaching and Teacher Education, 29, 122-131.

Roberts, T. M. \& Mcinnerney, J. M. 2007. Seven Problems of Online Group Learning (and Their Solutions). Educational Technology \& Society, 10(4), 257-268.

Salmon, G., Gregory, J., Lokuge Dona, K. \& Ross, B. 2015. Experiential online development for educators: The example of the Carpe Diem MOOC. British Journal of Educational Technology, 46, 542-556.

Smith, G. G., Sorensen, C., Gump, A., Heindel, A. J., Caris, M. \& Martinez, C. D. 2011. Overcoming student resistance to group work: Online versus face-to-face. Internet and Higher Education, 14, 121-128.

Trigwell, K. 2000. A phenomenographic interview on phenomenography. In: Bowden, J. A. \& Walsh, E. (eds.) Phenomenography. Melbourne: RMIT University Press.

Urhahne, D., Schanze, S., Bell, T., Mansfield, A. \& Holmes, J. 2010. Role of the Teacher in Computer-supported Collaborative Inquiry Learning. International Journal of Science Education, 32:2, 221-243.

Walsh, E. 2000. Phenomenographic analysis of interview transcripts. In: Bowden, J. A. \& Walsh, E. (eds.) Phenomenography. Melbourne, Australia: RMIT University Press.

Young, S. 2006. Student Views of Effective Online Teaching in Higher Education. The American Journal of Distance Education, 20(2), 65-77. 